\title{
Peran Modal Sosial dalam Pengelolaan Badan Usaha Milik Desa Maju Bersama di Desa Sei Jawi-Jawi Kecamatan Sei Kepayang Barat Kabupaten Asahan
}

\author{
The Role of Social Capital in the Management of Maju Village-Owned \\ Enterprises \\ Together in Sei Jawi-Jawi Village, Sei Kepayang Barat District, Asahan \\ Regency \\ Zulpahmi*, Badaruddin \& Humaizi
}

Magister Studi Pembangunan, Fakultas Ilmu Sosial Dan Ilmu Politik

Universitas Sumatera Utara, Indonesia

Diterima: 16 Januari 2020; Disetujui: 25 Maret 2020; Diterbitkan: 01 Juli 2020.

\begin{abstract}
Abstrak
BUMDes Maju Bersama adalah program pemerintah untuk membantu perekonomian masyarakat Desa Sei Jawi-jawi serta mencapai kesejahteraan masyarakat sehingga masyarakat sei jawi-jawi mendapatkan hidup yang cukup layak. Penelitian ini bertujuan untuk mengetahui peran modal sosial yang menjadi kekuatan penggerak dalam pengelolaan BUMDes Maju Bersama di Desa Sei Jawi-jawi Kecamatan Sei Kepayang Barat Kabupaten Asahan. Modal sosial memegang peran penting dalam memperkuat masyarakat Desa. BUMDes maju bersama bisa berkembang dengan adanya modal sosial. BUMDes Maju Bersama didirikan sebagai bentuk usaha untuk meningkatkan pembangunan ekonomi masyarakat desa serta menciptakan kemandirian bagi masyarakat di Desa Sei Jawi-jawi. Penelitian ini merupakan penelitian deskriptif kualitatif. Lokasi penelitian adalah di Desa Sei Jawi-jawi Kecamatan Sei Kepayang Barat Kabupaten Asahan. Objek penelitian ini adalah BUMDes Maju Bersama Desa Sei Jawijawi. Teknik pengumpulan data menggunakan teknik observasi, wawancara, dan dokumentasi. Hasil penelitian menunjukkan bahwa dalam pembentukan BUMDes Maju Bersama dilaksanakan dengan 3 (tiga) tahapan yaitu dengan tahap pra musyawarah desa, musyawarah desa dan pasca musyawarah desa. Jadi, Kegiatan musyawarah ini bertujuan untuk menetukan jenis BUMDes apa yang akan dibentuk dengan harapan dapat bermanfaat bagi masyarakat. Modal sosial berupa jaringan, Norma dan Kepercayaan yang berperan dalam pengelolaan BUMDes Maju Bersama dapat dikatakan belum cukup baik walaupun BUMDes Maju Bersama sudah beroperasional dan dapat memberikan kontribusi kepada Desa. Hal ini dilihat dari jaringan kerja sama BUMDes Maju Bersama masih sedikit, adanya agunan atau jaminan yang diberikan BUMDes, bunga yang diberikan oleh pengurus terlalu tinggi hampir sama dengan koperasi yang ada dan masih adanya penunggakan hutang masyakat. Adapun subjek informan dari penelitian ini adalah Kepala Desa, Perangkat Desa, Pengurus BUMDes Maju Bersama, Pengawas BUMDes, pihak yang mengetahui BUMDes dan Masyarakat yang mengentahui tentang BUMDes Maju Bersama.

Kata Kunci: Modal Sosial, Pembangunan, Sosial dan Ekonomi, BUMDes.
\end{abstract}

\section{Abstract}

BUMDes Maju Bersama is a government program to help the economy of the people of Sei Jawi-jawi Village and achieve community welfare so that the Sei Jawi-jawi people get a decent living. This study aims to determine the role of social capital which is a driving force in the management of the Joint Forward BUMDes in Sei Jawi-jawi Village, Sei Kepayang Barat District, Asahan Regency. Social capital plays an important role in strengthening village communities. BUMDes can advance together with social capital. BUMDes Maju Bersama was established as an effort to increase the economic development of rural communities and create independence for the people in Sei Jawi-jawi Village. This research is a qualitative descriptive study. The location of the study was in Sei Jawi-jawi Village, Sei Kepayang Barat District, Asahan Regency. The object of this research is BUMDes Maju Bersama Sei Jawi-jawi Village. Data collection techniques using observation, interviews, and documentation. The results showed that the formation of BUMDes Maju Bersama was carried out in 3 (three) stages, namely the pre-village deliberations, village deliberations and post-village deliberations. So, this deliberation activity aims to determine what type of BUMDes will be formed in the hope that it will benefit the community. Social capital in the form of networks, norms and beliefs that play a role in the management of BUMDes Maju Bersama can be said to be not good enough even though BUMDes Maju Bersama is already operational and can contribute to the Village. This can be seen from the BUMDes Maju Bersama cooperation network that is still small, with collateral or collateral provided by BUMDes, the interest given by the management is too high, almost the same as the existing cooperatives and there is still public debt arrears. The informant's subjects from this study were the Village Head, Village Officials, BUMDes Maju Bersama Management, BUMDes Supervisor, parties who knew BUMDes and the Community who knew about BUMDes Maju Bersama. Keywords: Social Capital, Development, Social and Economy, BUMDes.

How to Cite: Zulpahmi, Badaruddin \& Humaizi (2020). Peran Modal Sosial dalam Pengelolaan Badan Usaha Milik Desa Maju Bersama di Desa Sei Jawi-Jawi Kecamatan Sei Kepayang Barat Kabupaten Asahan. PERSPEKTIF, 9 (2): $168-182$
*Corresponding author:
ISSN 2085-0328 (Print)
E-mail: zulpahmiusu@gmail.com
ISSN 2541-5913 (online) 


\section{PENDAHULUAN}

Semangat reformasi tahun 1998, telah memberikan perubahan yang mendasar dalam perkembangan demokrasi di Indonesia. Otonomi daerah menjadi salah-satu konsep pembagian kekuasaan terhadap daerahdaerah. Otonomi daerah tersebut, telah mengubah paradigma model pembangunan yang sentralistik menjadi desentralisasi atau penyerahan wewenang kepada daerah-daerah. Otonomi daerah dan dentralisasi bukan hanya penyerahan kekuasaan. Namun juga memberikan kewenangan kepada pemerintahan daerah hingga desa untuk mengelola sumber daya alamnya (Widjaya, 2014).

Dengan potensi sumber daya alam yang dimiliki tersebut, mampu mencukupi kebutuhan seluruh warga masyarakat. Setiap wilayah atau desa memiliki potensi yang berbeda-beda, dimana potensi tersebut dimanfaatkan masyarakat desa untuk meningkatkan taraf perekonomian keluarga. Pembangunan Desa hakekatnya merupakan basis dari pembangunan nasional. Sebab, apabila setiap desa telah mampu melaksanakan pembangunan secara mandiri maka kemakmuran masyarakat akan mudah terwujud dan secara nasional akan meningkatkan indeks kemakmuran masyarakat Indonesia.

Pembangunan nasiaonal pada hakekatnya merupakan suatu usaha yang terencana untuk meningkatkan seluruh aspek kehidupan berbangsa dan bernegara. Adapun tujuan dari pembangunan itu sendiri adalah untuk mencapai kemandirian, termasuk pembangunan desa. Indonesia adalah negara agraria. Dari Sabang hingga Merauke, ujung Barat ke Timur, masyarakat sebagian besar mendiami desa-desa. Oleh karena itu, pembangunan desa merupakan kunci dalam pembangunan nasional. Kemajuan desa adalah cerminan peningkan pembangunan nasional di Indonesia (Adisasmita, 2006).

Pembangunan yang berbasiskan ekonomi pedesaan sebenarnya sudah semenjak lama dijalankan oleh pemerintah. Namun tingkat keberhasilannya belum secara optimal tercapai. Salah satu faktor yang paling dominan adalah intervensi pemerintah terlalu besar, akibatnya justru menghambat daya kreativitas dan inovasi masyarakat desa dalam mengelola dan menjalankan mesin ekonomi di pedesaan. Sistem dan mekanisme kelembagaan ekonomi di pedesaan tidak berjalan efektif dan berimplikasi pada ketergantungan terhadap bantuan pemerintah sehingga mematikan semangat kemandirian.

Menurut Sumpeno (2011), strategi pembangunan desa merupakan langkahlangkah yang akan ditempuh oleh seluruh perangkat organisasi, yang berisi program untuk mewujudkan visi, misi, dan tujuan yang ditetapkan. Beberapa strategi yang secara umum diimplementasikan dalam membangun kemandirian desa antara lain; (1) membangun kapasitas warga dan organisasi masyarakat sipil di desa yang kritis dan dinamis, (2) memperkuat kapasitas pemerintahan dan interaksi dinamis antara organisasi warga dalam penyelenggaran pemerintahan desa, (3) membangun sistem perencanaan dan penyelenggaraan desa yang responsif dan partisipatif, dan (4) membangun kelembagaan ekonomi lokal yang mandiri dan produktif.

Teori pertumbuhan ekonomi yang diketahui dari jurnal maupun buku bacaaan bahwa ada tiga modal yang menjadi kunci keberhasilan pembangunan suatu wilayah atau desa, yaitu modal alam, modal fisik, (uang dan bangunan), dan modal manusia. Ketiga macam modal tersebut seolah menjadi faktor penentu untuk keberhasilan suatu pembangunan.

Modal sosial diyakini sebagai salah satu komponen dalam menggerakkan kebersamaan, mobilitas ide, saling percaya, dan saling menguntungkan untuk mencapai tujuan bersama. Fukuyama (2001) menyakinkan bahwa modal sosial memegang peran yang sangat penting dalam memfungsikan dan memperkuat kehidupan masyarakat moderen. Modal sosial adalah kombinasi norma-norma yang berada dalam sistem sosial yang mengarah pada peningkatan kerja sama antar anggota masyarakat, dalam arti modal sosial bergantung pada hubungan individu dengan kelompok sosial sehingga dengan adanya modal sosial ini maka pembangunan ekonomi di desa dapat meningkat.

Pembangunan desa antara lain bertujuan mendorong prakarsa, gerakan dan partisipasi masyarakat desa untuk pengembangan potensi dan aset desa guna kesejahteraan bersama, serta memajukan perekonomian masyarakat Desa serta mengatasi kesenjangan 
pembangunan nasional. Namun saat ini masih sangat sedikit desa yang mampu mengembangkan potensinya. Hal ini disebabkan selama ini desa lebih banyak diposisikan sebagai obyek pembangunan sehingga sangat menggantungkan diri pada bantuan pemerintah pusat. Rendahnya kreatifitas sumberdaya manusia di desa sebagai akibat dari sistem pembangunan yang bersifat sentralistik pada masa lalu mengakibatkan banyak potensi dibiarkan terbengkalai tidak dikembangkan untuk sumber kemakmuran masyarakat. Sekarang saatnya kita membangun desa berbasis pada potensi desa yang dimiliki. (Kurniawan, 2015).

Asumsi itulah yang mendorong keberadaan desa mendapatkan perhatian yang serius dari pemerintah pusat dengan melahirkan kebijakan-kebijakan terkait pemberdayaan ekonomi yang dilakukan dengan cara menghimpun dan melembagakan kegiatan ekonomi masyarakat. Tahun 2015 merupakan tahun pertama dilaksanakannya UU No.6 Tahun 2014 Tentang desa, yang merupakan bagian dari ikhtiar mencapai keberdayaan negara dan bangsa Indonesia dari kemandirian desadesanya. Adapun untuk mewujudkan desa yang mandiri diperlukan adanya strategi pembangunan.

Kementerian Negara Pembangunan Daerah Tertinggal (KPDT) yang telah melakukan perubahan paradigma pembangunan daerah tertinggal yang sebelumnya berbasis pada kawasan menjadi berbasis pada pedesaan (Based on village). Dengan demikian, skala prioritas yang dilakukan KPDT bagi pembangunan daerah berbasis pedesaan antara lain mencakup: (1) pengembangan kelembagaan; pemberdayaan masyarakat; pengembangan ekonomi lokal, dan (4) pembangunan sarana dan prasarana. Skala prioritas tersebut diharapkan mampu menstimulus dan menggerakkan roda perekonomian di pedesaan dengan didirikannya lembaga ekonomi desa, yakni salah satunya adalah BUMDes (Badan Usaha Milik Desa).

BUMDes merupakan lembaga usaha desa yang dikelola oleh masyarakat dan pemerintahan desa dalam upaya memperkuat perekonomian desa dan dibentuk berdasarkan kebutuhan dan potensi desa. BUMDes merupakan pilar kegiatan ekonomi di desa yang berfungsi sebagai lembaga sosial (social institution) dan komersial (commercial institution). Pendirian BUMDes dilandasi oleh UU No. 32 tahun 2004 jo. UU No. 23 tahun 2014 tentang Pemerintahan Daerah, UU No. 6 tahun 2014 tentang Desa, PP No.43 tahun 2014 tentang Peraturan Pelaksanaan Undangundang nomor 6 tahun 2014 tentang Desa serta PP No. 47 tahun 2015 tentang Perubahan Peraturan Pelaksanaan Undang-undang nomor 6 tahun 2014 tentang Desa, Peraturan Menteri Desa, Pembangunan Daerah Tertinggal dan Trasmigrasi No. 4 tahun 2015 tentang Pendirian, Pengurusan dan Pembubaran Badan Usaha Milik Desa. Maka semakin jelas, bahwa BUMDes sebagai kerangka dasar otonomi daerah yang mengamanatkan dilaksanakannya perencanaan pembangunan dari bawah (Bottom- up planning) (Soemantri, 2011).

Sejak UU Desa No. 6 Tahun 2014 diterbitkan, semakin melegitimasi penguatan pengembangan Badan Usaha Milik Desa. Ide ini menjadi bagian penting dari bentuk pemberdayaan ekonomi masyarakat di tingkat desa sejak dimasukkan dalam klausul penting UU Desa. BUMDes ini mirip Badan Usaha Milik Negara (BUMN) di tingkat pemerintah pusat atau Badan Usaha Milik Daerah (BUMD) di tingkat pemerintahan daerah. Sebagaimana diatur dalam UU, BUMDes adalah badan usaha yang dimiliki pemerintah dan masyarakat di tingkat desa atau kerja sama antar desa yang mekanisme pembentukannya melalui musyawarah desa.

Sei Jawi-jawi merupakan salah satu desa yang ada di Kecamatan Sei Kepayang Barat Kabupaten Asahan Provinsi Sumatera Utara. Desa Sei Jawi-jawi mengembangkan BUMDes yang diberi nama BUMDes Maju Bersama.

BUMDes Maju bersama ini dibentuk dengan kesepakatan bersama melalui musyawarah Pemerintah Desa, Badan Perrmusyawaratan Desa dan Masyarakat Desa. BUMDes Maju Bersama ini bergerak di bidang Bank Desa/simpan pinjam sebagai prioritas utamanya. Dalam tahun 2016 BUMDes Maju Bersama membukukan laba bersih (SHU) sebesar Rp. 25.376.625 juta dengan modal awal sebesar Rp. 44 juta. Hal ini disampaikan Rabiah, Ketua BUMDes Maju Bersama dalam acara laporan tahunan BUMDes Maju Bersama Tahun 2016 di Aula Kantor Desa Sei Jawi-jawi. 
Dari hasil laba bersih itu, dialokasikan 40\% untuk dana penguatan modal, 20\% untuk Pendapatan Asli Desa (PADes), 20\% untuk dana pengurus, $10 \%$ dana cadangan serta masing-masing 5\% untuk dana sosial dan pendidikan. Setahun berdirinya BUMDes Maju Bersama ini langsung memberikan kontribusi dalam pembangunan ekonomi Desa dan kesejahteraan masyarakat Desa.

Ibu Rabiah selaku ketua BUMDes menjelaskan bahwa partisipasi masyarakat sangat aktif untuk mengembangkan BUMDes Maju Bersama, sehingga diklaim berdampak pada peningkatan kesejahteraan ekonomi masyarakat. Prinsip transparansi secara terperinci dalam menyampaikan laporan tahunan BUMDes Maju Bersama, menjadi pertama yang melaporkan hasil pertanggungjawaban se-Kabupaten Asahan.

Dalam 1 (satu) tahun beroperasi BUMDes di Desa Sei Jawi-jawi telah menunjukkan kontribusnya terhadap pembangunan ekonomi desa. Hal ini kemudian sangat menarik diteliti untuk memahami proses terbentuknya Badan Usaha Milik Desa dan bagaimana peran modal sosial dalam pengelolaan badan usaha milik desa sehingga mampu menggerakan pembangunan ekonomi Desa Sei Jawi-Jawi Kecamatan Sei Kepayang Barat. Meskipun sudah berjalanan selama 3 tahun namun BUMDes Maju Bersama memiliki beberapa masalah dalam pengembangannya. Berdasarkan Wawancara dari Ibu Rabiah selaku ketua BUMDes Maju Bersama, beliau mengatakab bahwa dalam pengembangan ini masih ada beberapa masalah yang kami alami yaitu kami masih membutuhkan banyak modal untuk pengelolaan BUMDes ini karena banyak permintaan masyarakat untuk peminjaman uang/modal untuk kelangsungan usaha mereka kemudian masalah berikutnya adalah ada juga beberapa masyarakat yang masih menunggak pembayran pinjaman mereka dalam arti masih ada masyarakat yang belum melunasi hutangnya, kemudian kami juga membutuhkan pelatihan BUMDes sehingga BUMDes ini tidak hanya bergerak di usaha simpan pinjam namun bisa kami kembangkan kepada bidang lain.

Melihat dari situasi dan Kondisi BUMDes Maju Bersama yang sudah dianggap berhasil maka hal inilah mendorong peneliti untuk mengkaitkan dengan Konsep Modal Sosial. Menurut Bourdieu (dalam Davin W, 2009:38) menjelaskan definisi modal sosial adalah jumlah sumber-sumber daya, aktual atau virtual (tersirat) yang berkembang pada seorang individu atau sekelompok individu karena kemampuan untuk memiliki suatu jaringan yang dapat bertahan lama dalam hubungan-hubungan yang lebih kurang telah diinstitusikan berdasarkan pengetahuan dan pengenalan timbal balik. Konsep definisi modal sosial lainnya yang sering digunakan adalah menurut Coleman (dalam Yustika, 2013:111) yang mendefinisikan modal sosial menurut fungsinya yaitu modal sosial itu bukanlah entitas tunggal, tetapi entitas majemuk yang mengandung dua elemen ertama, modal sosial mencakup beberapa aspek dari struktur sosial. Kedua modal sosial memfasilitasi tindakan tertentu dari pelaku dalam struktur tersebut.

Modal sosial selama ini dipandang memiliki peran dalam pengembangan suatu masyarakat dan menjadi kunci keberhasilan. Komponen modal sosial yaitu rasa saling percaya, jaringan kerjasama dan norma, dinilai mempunyai hubungan positif dengan pertumbuhan ekonomi wilayah terutama dalam interaksi ekonomi baik di negara berkembang maupun di negara maju (Vipriyanti, 2011).

Pentingnya peran modal sosial dalam pembangunan tersebut tentu saja ada hubungannya dengan pembangunan ekonomi desa yaitu pengelolaan BUMDes. Bahkan pentingnya modal sosial dalam pengelolaan BUMDes ini akan memberikan keuntungan yang baik terhadap individu maupun kelompok penerima manfaat sebab Modal sosial akan mengacu kepada hubungan antar invidu yakni kepercayaan, norma dan jaringan yang timbul dari individu ataupun kelompok tersebut.

Berdasarkan paparan di atas, maka peneliti tertarik untuk melakukan penelitian tesis dengan Judul Peran BUMDes Maju Bersama dalam Pengelolaan Badan Usaha Milik Desa Sei Jawi-jawi Kecamatan Sei Kepayang Barat Kabupaten Asahan Provinsi Sumatera utara.

\section{METODE PENELITIAN}

Adapun jenis penelitian dalam tesis ini adalah deskriptif kualitatif. Dalam penelitian deskkriptif kualitatif ini mengidentifikasi tentang proses pembentukan BUMDes Maju 
Bersama di Desa Sei Jawi-jawi. Dari proses tahapan pembentukan BUMDes Maju Bersama di Desa Sei Jawi-jawi, dan juga menganalisis peran Modal Soisal dalam pengelolaan Badan Usaha Milik Desa Maju Bersama di Desa Sei Jawi-jawi Kecamatan Sei Kepayang Barat.

Penelitian tesis ini dilakukan di Desa Sei Jawi-jawi Kecamatan Sei Kepayang Barat Kabupaten Asahan Provinsi Sumatera utara. Adapun alasan mengambil penelitian pada BUMDes Maju Bersama karena BUMDes ini merupakan salah satu BUMDes yang berhasil di Kabupaten Asahan dan dapat memberikan kontribusinya kepada pembangunan Desa Sei Jawi-Jawi. BUMDes Maju Bersama mampu memberikan Kontribusi berupa menambah PADesa. Selain dapat memberikan kontribusi terhdap PAD Desa, Dalam pengelolaannya BUMDes ini juga cukup baik dalam memberikan laporan tahunan terhadap perkembangan BUMDes Maju Bersama. Adapaun waktu pelaksanaan penelitian ini dilakukan pada tahun 2018

Penetapan informan dalam penelitian ini didasari dari kapasitas yang menyangkut konsep penelitian yaitu Peran Modal Sosial dalam Pembentukan dan Pengelolaan BUMDes Maju. Bersama di Desa Sei Jawi-Jawi Kecamatan Sei Kepayang Barat. Beberapa informan ini dapat memberikan berbagai data untuk dapat menjawab permasalahan penelitian. Adapun informan dalam penelitian ini adalah sebagai berikut: Kepala Desa Sei Jawi - Jawi Kecamatan Sei Kepayang Barat. Perangkat Desa Sei Jawi-Jawi sebanyak 1 (satu) orang. Pengurus BUMDes Sei Jawi-jawi Kecamatan Sei Kepayang Barat sebanyak 3 (tiga) orang. Masyarakat Desa pengguna layanan BUMDes sebanyak 7 (tujuh) orang. Pihak-pihak yang memahami BUMDes yaitu Pengawas BUMDes sebanyak 1 (orang).

Teknik Pengumpulan Data Wawancara dilakukan menggunakan pendekatan wawancara semi terstruktur dengan menggunakan petunjuk umum atau panduan wawancara. Wawancara ini dilakukan dengan Kepala Desa Sei Jawi-jawi, pengurus BUMDes Maju Bersama, petugas Pemerintahan Desa, Pengawas BUMDes dan masyarakat Desa yang mendapatkan bantuan pinjaman dari BUMDes Maju Bersama. Pemilihan subjek wawancara ini dengan mempertimbangkan pengetahuan subjek tentang informasi yang akan ditanyakan. Aspek pertanyaan wawancara mencakup tentang sejarah berdirinya BUMDes, peran kepercayaan, norma dan jaringan dalam Pengelolaan dan pengoperasian BUMDes Maju Bersama di Desa Sei Jawi-jawi Kecamatan Sei Kepayang Barat.

Dalam penelitian ini, dokumen internal yang digunakan antara lain struktur Profil Desa Sei Jawi-jawi, Buku Kecamatan Dalam Angka, data tingkat pengangguran, profil BUMDes, Peraturan Desa tentang BUMDes, Standar Operasional Prosedur serta laporan pertanggungjawaban BUMDes Maju Bersama. Sedangkan dokumen eksternal yang digunakan peneliti antara lain adalah korankoran local yang memuat berita tentang BUMDes Maju Bersama. Selain itu juga peneliti melakukan pencarian (searching) berita-berita yang berkaitan dengan pengelolaan Badan Usaha Milik Desa.

Kegiatan pengamatan terhadap objek penelitian ini untuk memperoleh keterangan data yang lebih akurat mengenai hal-hal yang diteliti serta untuk mengetahui relevansi antara jawaban informan dengan kenyataan yang terjadi di lapangan. Aspek observasi dalam penelitian ini adalah pengamatan terhadap kegiatan-kegiatan yang dilakukan oleh pengurus BUMDes dan Pemerintah Desa.

Adapun kegiatan yang diamati di lapangan adalah peneliti melihat dan mengamati proses kegitan simpan pinjam yang dilakukan oleh BUMDes Maju Bersama. Adapun kegiatan tersebut dilakukan di Kantor BUMDes Maju Bersama. Kemudian Peneliti juga mengamati Buku dan Dokumen penunjang BUMDes. Dokumen tersebut merupakan dasar hukum pengurus BUMDes untuk melakukan pengelolaan BUMDes. Dokumen tersebut berupa Laporan Tahunan BUMDes, Perdes tentang pembentukan BUMDes Maju Bersama dan AD/ART serta Standar Operasional Prosedur (SOP). Selain dalam bentuk dokumen, laporan kamajuan BUMDes Maju Bersama juga dituangkan di Papan Tulis pengumuman Kantor BUMDes Maju Bersama. Dalam Papan Tulis tersebut ditulis kemajuan BUMDes, Saldo BUMDes dan Pinjaman masyarakat serta tunggakan pinjaman masyarakat desa.

Sumber Data yang digunakan dalam penelitian ini adalah sebagai berikut: Data primer, berdasarkan hasil wawancara dari para informan dan buku laporan BUMDes Sei Jawi-jawi Kecamatan Sei Kepayang Barat 
Data Sekunder didapatkan dari bukubuku, jurnal, hasil penelitian terdulu, peraturan-peraturan dan media massa.

Langkah yang dilakukan dalam menganalisis data adalah; Pengumpulan data adalah mencari, mencatat, serta mengumpulkan data secara objektif dan apa adanya sesuai dengan hasil wawancara dengan informan penelitian dan dokumen di lapangan yang berkaitan dengan pembentukan dan pengelolaan BUMDes Maju Bersama di Desa Sei Jawi-jawi Kecamatan Sei Kepayang Barat.

Dalam penelitian ini peneliti mereduksi dan memilah data hasil observasi, wawancara, maupun dokumentasi. Karena data yang diperoleh dari lapangan masih kompleks dan bersifat mentah. Maka peneliti hanya akan memilih data yang benar-benar relevan berkaitan dengan peran modal sosial dalam pembentukan Badan Usaha Milik Desa Maju Bersama di Sei Jawi-Jawi Kecamatan Sei Kepayang Barat.

Data disajikan dalam bentuk teks narasi untuk menjelaskan proses pembentukan dn pengelolaan Badan Usaha Milik Desa Maju Bersama di Desa Sei Jawi-jawi serta peran modal sosial terhadap pembentukan dan pengelolaan Badan Usaha Milik Desa Maju Bersama. Dari data yang telah disajikan tersebut kemudian diolah berdasarkan teoriteori yang telah dikemukakan sebelumnya untuk memperoleh gambaran secara jelas. Keseluruhan data yang telah diolah peneliti tersebut kemudian dikumpulkan menjadi satu oleh peneliti kemudian disajikan hingga mencapai tahap kesimpulan.

Pengambilan kesimpulan diarahkan kepada hal-hal yang umum untuk mengetahui jawaban dari permasalahan. Permasalahan penelitian ini berkaitan dengan Modal Sosial dalam pembentukan dan pengelolaan Badan Usaha Milik Desa Maju Bersama di Desa Sei Jawi-jawi Kecamatan Sei Kepayang Barat

\section{HASIL DAN PEMBAHASAN \\ Proses Pembentukan BUMDes Maju Bersama}

Pembentukan BUMDes Maju Bersama di Desa Sei Jawi-jawi memiliki peran yang penting dalam perkembangan ekonomi masyarakat Desa Sei Jawi-jawi. BUMDes Maju Bersama mulai berproses pada akhir 2015. Dengan dibentuknya BUMDes ini dapat membantu masyarakat desa dalam pemodalan usaha sehingga meningkatkan kehidupan ekonomi masyarakat desa.

Dengan dibentuknya BUMDes Maju Bersama memberikan kemudahan kepada masyarakat untuk memperoleh modal untuk mengembangkan usaha masyarakat Desa Sei Jawi-jawi. Namun peminjaman uang hanya diperuntukan kepada masyarakat yang mempunyai usaha untuk menambah modal usaha bukan untuk kebutuhan membeli alat rumah tangga atau sebagainya.

Malik (2016) menyatakan bahwa Pembentukan BUMDes dimaksudkan sebagai upaya bersama antara masyarakat dengan pemerintah desa untuk mengembangkan potensi ekonomi desa dan kebutuhan masyarakat guna mengingkatkan kesejahteraan seluruh masyarakat dan berkontribusi bagi pendapatan desa.

Salah satu Tujuan pembentukan atau Pendirian Badan Usaha Milik Desa (BUMDes) berdasarkan Permendesa PDT dan Transmigrasi NO. 4 Tahun 2015 adalah untuk meningkatkan perekonomian desa dan meningkatkan usaha masyarakat dalam pengelolaan potensi ekonomi desa. Sasaran dari pembentukan BUMDes ini adalah untuk melayani masyarakat desa dalam mengembangkan usaha produktif.

Malik (2016) menjelaskan bahwa Pendirian BUMDes dimaksudkan sebagai upaya bersama antara masyarakat dengan pemerintah desa, untuk mengembangkan potensi ekonomi desa dan kebutuhan masyarakat guna meningkatkan kesejahteraan seluruh masyarakat dan berkontribusi bagi pendapatan desa. Namun pendirian BUMDes hendaknya dipersiapkan dengan baik dan matang agar tidak menimbulkan permasalahan dikemudian hari.

Pembentukan BUMDes Maju Bersama di Desa Sei Jawi-jawi dilakukan dengan beberapa Tahapan. Adapun tahap-tahapnya adalah sebagai berikut: Tahap Pertama (Pra Musyawarah Desa): Melakukan Sosialisasi kepada warga Desa Sei Jawi-jawi mengenai pembentukan BUMDes. Sosialisasi yang ini dilakukan dengan tujuan untuk memberikan pemahaman kepada masyarakat tentang Badan Usaha Milik Desa (BUMDes), bagaimana cara kerja nya dan bagaimana cara pembentukan serta keuntungan dengan adanya BUMDes. Dalam sosialisasi tersebut juga menampung ide atau gagasan serta saran 
dari masyarakat atau pemerintah desa untuk kelangsungan terbentuknya BUMDes. Kegiatan sosialisasi ini dihadiri oleh stakeholder terkait dan masyarakat setempat. Bapak Daud selaku Kepala Desa Sei Jawi-jawi menjelaskan bahwa ada beberapa orang yang hadir pada acara sosialisasi tentang pembentukan BUMDes Maju Bersama diantaranya adalah pihak Pemerintah Kabupaten sebagai Narasumber, pihak Kecamatan, Pemerintah Desa, BPD, LPM, Tokoh Agama dan Tokah Masyarakat. Dan harapan kami program BUMDes Maju Bersama dapat berjaya sampai kedepannya serta dapat dukungan dari seluruh masyarakat desa Sei Jawi-jawi.

Melakukan pembahasan mengenai pemetaan kebutuhan warga desa. Melakukan kajian ringkas mengenai potensi apa yang ada di desa dan apa saja yang dibutuhkan oleh masyarakat desa untuk menunjang dan mengembangkan ekonomi desa. Pada hal ini masyarakat Desa Sei Jawi-jawi membutuhkan modal usaha untuk mengembagkan usaha yang mereka jalani.

Penyusunan Draf Anggaran Dasar dan Anggaran Rumah Tangga BUMDes Maju Bersama. Penyusunan Draf Anggaran Dasar dan Anggaran Rumah Tangga BUMDes dilakukan oleh perangakat Pemerintah Desa beserta masyarakat. Draf AD/ART inilah yang akan dibahas ketika Musyawarah Desa. Bapak Heri selaku Sekdes Sei Jawi-jawi mengatakan bahwa pihak Desa membentuk tim untuk menyusun Draf AD/ART dan kami juga berkonsultasi kepada pihak kecamatan yaitu Kasi PMK Kecamatan Sei Kepayang Barat dan Dinas PMD Kabupaten Asahan untuk tindak lanjut penyusunan AD/ART untuk BUMDes Maju Bersama.

Menentukan kriteria kepengurusan organisasi pengelola BUMDesa.. Dalam penentuan kriteria kepengurusan BUMDes Maju Bersama harus memiliki komitmen yang kuat dalam pengembangan ekonomi desa serta memahami kondisi Desa Sei Jawi-jawi. Bapak Heri selaku Sekdes mengatakan bahwa kriteria yang kami pilih sebagai pengurus BUMDes adalah memiliki pemahan dan pengalaman mengenai pengelolaan keuangan serta berkomitmen untuk kemajuan BUMDes dan juga pengurusnya harus berdomisili di desa ini sehingga beliau paham tentang kondisi Desa Sei Jawi-jawi.
Tahap Kedua (Musyawarah Desa), Undang-undang No.6 Tahun 2014 tentang Desa menyebutkan bahwa Musyawarah Desa atau yang disebut dengan nama lain adalah Musyawarah antara Badan Permusyawaratn Desa, Pemerintah Desa dan unsur masyarakat yang diselenggarakan oleh Badan Permusyawaratan Desa untuk menyepakati hal yang bersifat startegis. Pada Pasal 54 Undang-undang Desa bahwa lebih lanjut menjelaskan salah satu hal yang dianggap startegis adalah pembentukan BUMDes. Kegitan Musyawarah Desa dilakukan untuk mendapatkan kesepakatan tentang pembentukan Badan Usaha Milik Desa (BUMDes). Musyawarah ini dihadiri oleh Ketua BPD, Anggota BPD, Perangkat Desa dan perwakilan Masyarakat dan Musyawarh dipimpin langsung Kepala Desa dan Ketua BPD.

Adapun hal-hal pokok yang dibahas
dalam Musyawarah Desa meliputi: Menyampaikan hasil pemetaan dan jenis usaha. Hasil pemetaan dan pemilihan jenis usaha yang dibentuk untuk BUMDes Maju Bersama disampaiakan pada Musyawarah Desa, dan Musyawarah Desa ini dihadiri oleh Pihak-pihak terkait seperti Pemerintah Desa, BPD, dan Tokoh Masyarakat. Menyepakati pendirian BUMDes sesuai dengan kondisi ekonomi.

Membahas AD/ART. Malik (2016) menjelaskan bahwa AD/ART BUMDes adalah dokumen penting yang menunjukkan tata kelola BUMDes dan Mekanisme pertanggungjawabannya sebagai lembaga ekonomi yang melaksanakan usaha bisnis milik desa. Pada dasarnya Anggaran dasar BUMDes memuat paling sedikit Nama, Tempat, Kedudukan, Maksud dan Tujuan, Modal, Kegiatan Usaha, Jangka Waktu berdirinya BUMDes, Organisasi pengelola serta tata cara penggunaan dan pembagian keuntungan.

Ibu Rabiah selaku Ketua BUMDes mengatakan bahwa pada musyawarah Desa kemaren kami membahas tentang anggaran dasar Badan Usaha Milik Desa bersama seluruh peserta musyawarah, jadi isi dari pembahasannya ada mengenai lokasi dari BUMDes, Visi dan Misi dan juga asas, fungsi dan prinsip dibangunnya BUMDes Maju Bersama. Kami juga membuat AD/ART BUMDes Maju bersama dalam bentuk dokumen/berkas jadi dokumen tersebut 
sebagai arsip dan pertanggungjawaban kami dalam mengelola BUMDes Maju Bersama.

Pemilihan kepengurusan atau pengelola BUMDes Maju Bersama. Pemilihan kepengurusan BUMDes harus sesuai dengan kriteria dan kentuan yang berlaku. Persyaratan dan kriteria menjadi kepengurusan BUMDes menurut pasal 14 Permendesa PDT dan Transmigrasi No.4 Tahun 2015 tentang BUMDes meliputi masyarakat Desa yang meiliki jiwa wirausaha, berdomisili dan menetap di Desa sekurangkurangnya 2 (dua) Tahun, kepribadian baik, jujur, adil, cakap, dan perhatian terhadap usaha ekonomi Desa, dan berpendidikan minimal SLTA atau sederajat.

Pemerintah Desa dan masyarakat telah memilih kepengurusan BUMDes sesuai dengan peraturan yang berlaku serta memilih pengurus yang memilki pengetahuan tentang pengelolaan keuangan serta memiliki komitmen yang tinggi untuk mengelola BUMDes menjadi usaha yang menguntungkan bagi masyarakat dan pemerintah Desa.

Penyampaian Sumber Pemodalan BUMDes Maju Bersama. Penyampaian Pemodalan BUMDes dibahas pada pelaksanaan Musyawarah Desa. Malik (2016) mengatakan Modal awal BUMDes berasal dari pernyataan modal desa yang dialokasikan melalui anggaran pendapatan dan belanja desa (APBDes). Modal awal untuk BUMDes tidak harus berasal atau dialokasikan dari transfer dana desa. Modal awal untuk BUMDes dapat diaolokasikan dari dana manapun yang sudah masuk ke rekening desa sebagai pendapatan desa di dalam APBDes.

UU No.6 Tahun 2014 tentang Desa menjelaskan Pendapatan Desa terdiri dari 7 (tujuh) sumber yaitu Pendapatan Asli Desa, Transfer Dana Desa dari APBN, Bagian dari hasil pajak daerah dan retribusi daerah Kabupaten/Kota (paling sedikit 10\% dari pajak dan retribusi daerah, Alokasi Dana Desa (ADD) yang merupakan bagian dari dana perimbangan yang diterima Kabupaten/Kota, Bantuan Keuangan dari Anggaran Pendapatan dan Belanja Daerah Kabupaten/Kota, Hibah dan sumbangan yang tidak mengikat dari pihak ketiga dan lain-lain pendapatan desa yang sah seperti contoh kerjasama dengan pihak ketiga atau bantuan perusaan/CSR.

Ibu Rabiah selaku Ketua BUMDes menjelaskan bahwa sumber pemodalan awal dari BUMDes Maju Bersama Desa Sei Jawi-Jawi ini berasal dari penyertaan modal desa yang dialokasikan pada APBDes kemudian diberikan kepada pengurus BUMDes untuk dikelola, kemaren kai mendapatkan penyertaan modal sebesar Rp. 44.644.439. itu lah modal awal kami untuk mengelola BUMDes Maju Bersama ini.

Tahap Ketiga (Pasca Musyawarah Desa). Menyusun Rancangan Peraturan Desa tentang Penetapan Pendirian Badan Usaha Milik Desa yang mengacu pada UU Desa, Peraturan Pelaksanaan dan Peraturan Menteri Desa, Pembangunan Daerah Tertinggal dan Transmigrasi. Dalam Pemendagri No.111 Tahun 2015 tentang Pedoman Teknis Peraturan di Desa menerangkan bahwa Peraturan Desa adalah peraturan perundangundangan yang ditetapkan oleh Kepala Desa setelah dibahas dan disepakati bersama Badan Permusyawaratan Desa (BPD). Rancangan Peraturan Desa mengenai pembentukan dan pengelolaan Badan Usaha Milik Desa disusun oleh pihak pemerintah desa untuk dibahas bersama Badan Permusyawaran Desa. Bapak Heri selaku Sekdes Sei Jawi-jawi menjelaskan bahwa kami membuat rancangan perdes mengenai pembentukan dan pengelolaan BUMDes Maju Bersama setelah acara musyawarah desa mengenai pembentukan BUMDes Maju Bersama selesai kemudai rancangan itu dibahas bersama Badan Permusyaratan Desa Sei Jawi-jawi.

Dari paparan Sekdes di atas bahwa ketika Musyawarah Desa mengenai pembentukan BUMDes Maju Bersama di Desa Sei Jawi-jawi selesai dan mendapat kesepakatan bersama maka pihak Pemerintah Desa membuat suatu rancangan Peraturan Desa tentang Pembentukan dan Pengelolaan Badan Usaha Milik jDesa Maju Bersama. Rancangan ini dibahas bersama Badan Permusyawaratan Desa Sei Jawi-jawi.

Pembahasan Rancangan Peraturan Desa dilakukan bersama-sama antara Pemerintah Desa dan Badan Permusyawaran Desa. Setelah BPD menyetujui atas Rancangan Peraturan Desa tersebut maka akan ditetapkan Peraturan Desa tentang Pendirian Badan Usaha Milik Desa. Penetapan Peraturan Desa tentang Penetapan Pendirian Badan Usaha Milik Desa. 


\section{Peran Modal Sosial terhadap Pengelolaan BUMDes Maju Bersama}

Modal sosial diyakini sebagai salah satu komponen dalam menggerakkan kebersamaan, mobilitas ide, saling percaya, dan saling menguntungkan untuk mencapai tujuan bersama. Fukuyama (2001) menyakinkan bahwa modal sosial memegang peran yang sangat penting dalam memfungsikan dan memperkuat kehidupan masyarakat moderen. Modal sosial adalah kombinasi norma-norma yang berada dalam sistem sosial yang mengarah pada peningkatan kerja sama antar anggota masyarakat. Secara konseptual modal sosial bisa dikatakan sangat bergantung kepada hubungan sosial. Implikasinya jika dilihat pada individunya maka fitur yang dimaksud adalah norma, nilainilai atau secara umum kekayaan budaya struktural. Jika dengan fitur tersebut berhasil diciptakan dalam sebuah relasi antara manusia dengan manusia lainnya maka secara tidak langsung sesungguhnya telah tercipta apa yang disebut oleh fukuyama sebagai modal sosial.

Hasil dari musyawarah dan rembuk warga, Pemerintah Desa Sei Jawi-jawi menetapkan pendirian BUMDes Maju Bersama Desa Sei Jawi-jawi pada tanggal 02 Oktober 2015, Musyawarah tersebut dihadiri oleh Kepala Desa, BPD, Tokoh Masyarakat dan Tokoh Agama Desa. Berdirinya BUMDes tersebut juga didasari oleh keputusan diterbitkannya Undang-Undang No 8 Tahun 2005 tentang perubahan atas Undang-Undang No 32 Tahun 2004 tentang Pemerintah Daerah sebagaimana diamanatkan dalam Bab VII bagian kelima yang menyatakan Pemerintah Desa dapat mendirikan Badan Usaha Milik Desa sesuai dengan kebutuhan dan potensi desa. Dengan harapan dapat meningkatkan pendapatan masyarakat desa tersebut. Pendirian BUMDes Maju Bersama juga diperkuat dengan penetapan Peraturan Desa Sei Jawi-jawi tentang Pembentukan BUMDes Maju Bersama Desa Sei Jawi-jawi.

Peran Jaringan. Jaringan sosial adalah suatu hubungan sosial yang melibatkan sekelompok orang dengan nilai-nilai atau norma-norma informal disamping nilai-nilai atau norma-norma yang diperlukan untuk dapat menghubungkan orang yang dipandang sebagai titik dan hubungan sosial dipandang sebagai suatu saluran untuk mengalirkan sesuatu.
Modal sosial bentuk jaringan yang dibangun dalam pengelolan BUMDes memungkinkan terjadinya kemudahan mendapatkan dukungan dalam pemberdayaan ekonomi masyarakat, kemudahan mendapatkan informasi kebutuhan masyarakat pemanfaatan BUMDes, perasaan ikut memiliki, memperkuat komitmen kerja, kemudahan menyusun rencana kerja, dan terjaminnya pemenuhan kebutuhan pemanfaat BUMDes serta peningkatan pelayanan bagi masyarakat pemanfaat BUMDes agar tetap terpuaskan.

Berdasakan penelitian yang telah dilakukan, ditemukan bahwa dalam pengelolaan BUMDes Maju Bersama ada pihakpihak yang tergabung atau terlibat dalam pembentukan dan pengelolaan BUMDes Maju Bersama, adapun pihak-pihak yang terlibat anatara lain:

Masyarakat Desa Jawi-jawi. Jaringan ini terbentuk karena masyarakat Desa Jawi-jawi sebagai anggota pengelola BUMDes Maju Bersama melalui rekruitmen anggota pengelola BUMDes bergerak bersama kepala Desa Sei Jawi-jawi membentuk BUMDes Maju Bersama. Masyarakat Desa Sei Jawi-jawi juga sebagai nasabah atau mitra usaha BUMDes Maju Bersama dalam berinvestasi demi kelangsungan BUMDes Maju Bersama.

Setiap masyarakat Desa sei jawi-jawi Kecamatan Sei Kepayang Barat boleh mengajukan permohonan pinjaman dana kepada BUMDes Maju Bersama namun demikian masyarakat harus memenuhi persyaratan yang telah ditetapkan oleh pengurus Bumdes Maju Bersama sehingga permohonan pinjaman segera diproses dan ditindaklanjuti oleh pengurus BUMDes Maju Bersama.

BUMDes Maju Bersama, juga melakukan musyawarah kepada tokoh masyarakat dan Kepala Desa. Musywarah ini dilaksanakan di Kantor Balai Desa Sei Jawi-jawi, karena kantor BUMDes Maju Bersama terletak 1 (satu) lokasi dengan Balai Desa. Tujuan dilakukannya musyawarah ini untuk membentuk pola pikiran masyarakat, untuk bersama membangun dan mengembangkan potensi desa yang dimiliki serta mengevaluasi mengenai keberadaan BUMDes.

Selain melakukan musyawarah tahunan, BUMDes maju bersama juga memberikan santunan atau bantuan kepada masyarakat 
kurang mampu berupa paket sembako. Keberadaan BUMDes Maju bersama ini pastinya memiliki manfaat terhadap desa sei jawi-jawi dan juga kepada masyarakat setempat. Adanya bantuan pendanaan ini memberikan keringanan kepada masyarakat dalam pemodalan usaha mereka.

Dari penjelasan ibu Misbun tersebut bahwa dengan adanya BUMDes maju Bersama ini memberikan kemudahan bagi masyarakat desa untuk memperoleh modal usaha. Terbentuknya BUMDes ini sangat bermanfaat bagi masyarakat, manfat lain adalah adanya keuntungan dari kedua belah pihak, yang mana BUMDes memperoleh keuntungan dari hasil persen pinjaman modal tersebut sehingga dapat menambah PADes kepada Desa sei jawi-jawi. Begitu pula dengan masyarakat, manfaat yang diterima adalah mereka mendapatkan modal untuk mengembangkan usaha dan ekonomi masyarakat tersebut

Instansi Pemerintah. Kedudukan Badan Usaha Milik Desa (BUMDes) Maju Bersama dalam hal ini adalah membantu pemerintahan daerah untuk mendorong berkembangnya perekonomian desa melalui kreativitas peluang usaha ekonomi produktif (berwirausaha) dan juga membantu Pemerintah Desa untuk memperoleh pendapatan asli Desa Sei Jawi-jawi.

Dari hasil wawancara terhadap Kepala Desa Sei Jawi-jawi bahwa Badan Usaha Milik Desa (BUMDes) Maju Bersama telah mampu memberikan kontribusinya kepada Desa Sei jawi-jawi, salah satunya adalah BUMDes mampu menambah Pendaparan Asli Desa (PADes). Hal ini dibuktikan dengan laporan tahunan BUMDes Maju Bersama.

Pihak Swasta (Pihak Ketiga). UD Izzara dan CV Akbar Jaya merupakan pihak swasta atau pihak ketiga yang mengembangkan pola kemitraan dengan BUMDes Maju Bersama. Kedua instansi swasta ini, tentu memberikan sumbangsih besar untuk meningkatkan pembangunan ekonomi Desa Sei Jawi-jawi. Jaringan yang terbangun diantara BUMDes Sei Jawi-jawi dengan pihak ketiga ini, menunjukkan adanya hubungan yang saling menguntungkan dari segi bisnis.

Di satu sisi pihak ketiga menjadi salahsatu roda penggerak aktivitas perekonomian di BUMDes Maju Bersama, di sisi lain permodalan BUMDes Maju Bersama ke pihak ketiga semakin memberikan sedikit kemajuan terhadap BUMDes,

Melakukan jaringan kepada pihak ketiga diharapkan mampu mengembangkan BUMDes Maju Bersama menjadi lebih baik. Hal ini lah yang dilakukan oleh pengurus BUMDes melakukan kerjasama kepada pihak ketiga yang ada di Desa Sei Jawi-jawi. Walupun hanya 2 (dua) $\mathrm{Cv}$ yang berjejaring dengan BUMDes Maju Bersama namun harapan dari pengurus BUMDes, mereka mampu mengembangkan dan bisa bekerjasama dengan BANK Komersial yang ada di Desa Sei Jawi-jawi.

Adanya peran jaringan ini memberikan keuntungan bagi BUMDes dan juga pihak yang bersangkutan. Sehinga keberadaan jaringan menumbuhkan kerjasama yang baik antara keduanya. Hal ini juga berkaitan dengan penelitian terdahulu yang dilakukan oleh Syahputra (2015). Penelitian tersebut membahas tentang BUMDes Al-Madina dalam Perspektif Modal Sosial James S. Coleman (Penelitian tentang Pengembangan Perekonomian Desa). Hasil temuan dari penelitiannya adalah modal sosial untuk pengembangan ekonomi Desa Tumerejo melalui serangkaian hubungan yang dilakukan oleh BUMDes Al-Madina dengan pihak lain yang berkompeten berperan menciptakan jaringan sosial dalam bentuk kerjasama. Keberadaan jaringan sosial tersebut menciptakan lingkaran kerjasama dalam pelaksanaan program pengembangan ekonomi desa. Adanya jaringan sosial memberikan manfaat bagi terbukanya pengetahuan, informasi, pengalaman dan akses kekuasaan bagi terbentuknya sember daya manusia yang berkualitas sehingga pengembangan BUMDes Al-Madina dapat berkembang sampai saat ini. penelitian tersebut berkaitan dengan penelitian ini bahwa dibutuhkan modal sosial supaya BUMDes dapat beroperasi dengan baik. Dan adanya peran jaringan sosial sangat membantu dalam pengelolaan BUMDes sebab jaringan sosial membentuk kerjasama antara BUMDes dengan Masyarakat sehingga akan diperoleh mitra kerja.

Penelitian terdahulu yang juga berkaitan dengan penelitian ini adalah Yudiardi (2015) Beliau membahas tentang Strategi Pengembangan BUMDes Dalam Meningkatkan Perekonomian Masyarakat Pedesaan Kabupaten Garut. Adapun kesimpulan dari penelitiannya adalah Perumusan strategi 
pengembangan BUMDes dilakukan dengan menganalisis faktor internal dan eksternal BUMDes. Analisis tersebut digunakan untuk mengetahui kekuatan, kelemahan, peluang dan ancaman yang dimiliki oleh BUMDes. Hasil analisis kemudian digunakan untuk melakukan pembobotan dan penentuan rating sehingga diketahui posisi BUMDes saat ini yaitu dalam posisi yang baik dan strategi yang dapat diterapkan adalah grow and build strategy. Alternatif strategi kemudian disusun berdasarkan posisi BUMDes saat ini dan berdasarkan analisis kekuatan, kelemahan, peluang dan ancaman melalui matriks SWOT. Kemudian Pembentukan ikatan kerjasama dengan lembaga pengembangan lain merupakan prioritas strategi yang dapat diterapkan dalam upaya pengembangan BUMDes. Kaitannya dengan penelitian ini adanya kerja sama dengan lembaga lain. BUMDes Maju Bersama juga melakukan kerjsama dengan pemerintah desa, masyarakat desa dan beberapa CV yang ada di Desa Sei Jawi-jawi. Ini dilakukan supaya masyarakat dapat meningkatkan ekonominya dan juga bisa memberikan kontribusi dalam pembangunan Desa Sei Jawi-jawi.

Pada masyarakat Desa Sei Jawi-jawi, norma dan nilai kehidupan budaya masih tercermin dalam kehidupan sehari-hari. Mereka tetap mempertahankan budaya "Saling Bantu-membantu" yang merupakan modal sosial yang kuat untuk mengantisipasi prilakuprilaku negatif seperti kecurangan dan individualisme yang dapat mengancam kegiatan usaha. Peran BUMDes dalam pengelolaan dana pinjaman sangat dijunjung tinggi oleh masyarakat setempat. Pengelolaan dana pinjaman BUMDes relatif bisa di handle, meskipun dalam prakteknya pekerjaan pengelola bukan sebagai pengurus BUMDes saja. Peran dalam pelayanan BUMDes sangat menentukan tingkat keberhasilan program yang sedang dijalankan.

Mawardi M. J. (2007) berargumen norma sosial akan sangat berperan dalam mengontrol bentuk-bentuk perilaku yang tumbuh dalam masyarakat. Norma-norma ini biasanya terinstitusionalisasi dan mengandung sangsi sosial yang dapat mencegah individu berbuat sesuatu yang menyimpang dari kebiasaan.

Norma sosial yang ada di Badan Usaha Milik Desa (BUMDes) Maju Bersama secara tertulis tertuang dalam anggaran dasar dan anggaran rumah tangga (AD/ART) Badan Usaha Milik Desa (BUMDes) Maju Bersama yang diresmikan pada 02 Oktober 2015 di Desa Jawi-jawi. AD/ART ini digunakan untuk menjalankan organisasi/lembaga sosial Badan Usaha Milik Desa (BUMDes) Maju Bersama. Prinsip pengelolaan BUMDes Maju Bersama yang dicantumkan di AD/ART dan SOP peminjaman yang merupakan wujud norma yang diterapkan.

Sedangkan aspek norma profesionalisme dapat dilihat juga dari pemberian pinjaman oleh BUMDes Maju Bersama ke warga desa Sei jawi-jawi. Terdapat beberapa persyaratan peminjaman yakni peminjaman bagi warga yang mengembangkan usahanya, peminjaman harus disertai jaminan dan siap diaudit apakah layak atau tidak menerima pinjaman. Sebagaimana hasil wawancara peneliti dengan pengurus BUMDes Maju

BUMDes Maju Bersama menerapkan efisiensi dalam mengoperasionalkan aktivitas ekonominya. Pengurus berusaha untuk meminimalisir pengeluaran seperti anggaran rapat-rapat, pembinaan, dan urusan administrasi. Nilai efisiensi dijadikan sebagai internalisasi dalam menjalankan aktivitas ekonomi, sehingga berdampak pada penekanan pengeluaran dan dapat meningkatkan dengan profit yang maksimal bisa dicapai.

Sementara norma transparansi dapat dilihat dari penyajian laporan keuangan secara rutin diterbitkan setiap bulan di papan pengumuman kantor. Jadi, seluruh warga desa Sei Jawi-jawi dapat mengakses laporan keuangan baik pengeluaran dan pendapatan BUMDes Maju Bersama. Demikian dengan hasil-hasil rapat, juga dimuat di papan pengumuman di kantor BUMDes Maju Bersama. Sehingga masyarakat dapat mengetahui seluruh informasi maupun ativitas dari pengurus BUMDes Maju Bersama. Pengurus BUMDes Maju Bersama juga mempunyai SOP terkait keluh kesah warga desa khususnya nasabah/mitra terhadap BUMDes Maju Bersama.

Dalam norma partisipasi dan demokrasi, seluruh warga desa Sei Jawi-jawi mempunyai hak yang sama untuk dipilih dan memilih pengurus BUMDes Maju Bersama. Tidak ada diskriminasi yang membedakan suku, agama, ras dan golongan, semua mempunyai hak dan 
kewajiban yang sama dalam BUMDes Maju Bersama.

Norma yang tertulis yang mengatur hubungan kerjasama antara Pengurus BUMDes Maju Bersama dengan Nasabah/Mitra, dituangkan sebagaimana dalam AD/ART maupun SOP-SOP yang diberlakukan oleh BUMDes Maju Bersama yang ditetapkan dalam Musyawarah bersama pemerintah desa dan pengurus BUMDes maju bersama.

Subki (2011) menyatakan bahwa Kepercayaan (trust) muncul jika suatu kelompok terdapat nilai (shared value) sebagai dasar dari kehidupan untuk mencapai pengharapan umum dan kejujuran. Kepercayaa yang tumbuh didalam pengelolaan BUMDes Maju Bersama adalah adanya bukti pembentukan BUMDes Maju Bersama berupa Peraturan Desa Sei Jawi-jawi tentang Pembentukan BUMDes Maju Bersama.

Kedudukan BUMDes Maju Bersama adalah benar adanya dengan dibuktikan oleh Peraturan desa tentang BUMDes Maju Bersama. Hal ini dilakukan untuk memperkuat kedudukan tentang keberadaan BUMDes Maju Bersama dan memberikan rasa aman dan percaya kepada masyarakat sehingga masyarakat tidak takut atau khawatir dalam bermitra kepada BUMDes Maju Bersama. Selain itu di dalam Standar Operasional Prosedur (SOP) dalam melakukan pinjaman di BUMDes Maju Bersama telah jelas diterangkan bahwa masyarakat harus memunuhi persyaratan dalam meminjam uang, dan peminjam harus adanya jaminan pinjaman seperti BPKP kendaraan ataupun surat berharga lainnya sebagai jaminan untuk peminjaman uang, tujuannya adalah supaya masyarakat memiliki tanggungjawab untuk membayar hutang mereka.

Keberadaan BUMDes Maju Bersama namun ketika masyarakat yang ingin meminjam uang, masyarakat peminjam harus menyerahkan jaminan peminjam supaya pinjaman dapat diproses.

Dari uraian di atas, hal ini juga sama seperti penelitan terdahulu yang dilakukan oleh Pandi (2016). Judul dari penelitiannya adalah Peran Modal Sosial Terhadap Keberlangsungan Usaha Pedagang Burjo Di Salatiga. Penelitian ini menggunakan metode kualitatif. Peneltian Pandi memiliki fokus kajian pada keberlangsungan usaha melalui modal sosial dengan unit amatan pedagang
Burjo di Salatiga. Hasil penelitiannya adalah modal sosial terbentuk karena terjadinya proses jual beli antara pedagang Burjo dan pembeli, kemudian adanya ikatan saling percaya (trust) dan membangun ikatan kekerabatan atau jaringan dalam kesepakatan bersama sehingga menghasilkan usaha burjo yang terus maju dan berkembang. Kaitannya dengan penelitian ini adalah adanya saling percaya antara BUMDes Maju Bersama dan masyarakat, kepercayaan tersebut juga didasari dengan adanya SOP dan Peraturan Desa tentang BUMDes Maju Bersama sehingga memberikan rasa percaya dan aman terhadap masyarakat.

Menurut Pretty dan Ward (2000) bahwa Terdapat dua macam kepercayaan, kepercayaan terhadap individu yang kita mengenalnya, dan kepercayaan terhadap orang yang kita tidak tahu, namun akan meningkat karena kenyamanan kita dalam pengetahuan struktur sosial. Jadi untuk memberikan kepercayaan dalam memberikan pinjaman modal kepada masyarakat, nasabah yang ingin meminjam uang harus memiliki jaminan,

Masyarakat Desa Sei jawi-jawi ingin melakukan permohonan pinjaman uang kepada BUMDes Maju Bersama, maka masyarakat tersebut harus memiliki sebuah jaminan, seperti surat berharga ataupun BPKB kendaraan sehingga pihak pengurus BUMDes akan memberikan pinjaman sesuai diinginkan, dan itu juga diberikan setelah melakukan survei lapangan terhadap sipeminjam uang.

Pembentukan dan pengelolaan Badan Usaha Milik Desa (BUMDes) Maju Bersama nantinya menjadi forum pemberdayaan potensi Desa Sei Jawi-jawi. Dengan harapan pengelolaan BUMDes harus aktif dan memiliki inovasi dan gagasan untuk lebih mengembangkan BUMDes Maju Bersama sehingga kedepannya BUMDes Maju Bersama dapat mengembangkan potensi desa dan kegaitan lain selain simpan pinjam.

Pemerintahan Desa Sei Jawi-jawi juga mengembangkan kegiatan sosial, seperti memberikan santunan, pelatihan keterampilan, dan pelatihan dalam pengurusan BUMDes. Dalam bidang ekonomi berupaya menumbuhkan semangat wirausaha bagi masyarakat melalui bantuan modal dan pelatihan. 
Pemberian santunan tersebut merupakan salah satu program dari BUMDes Maju Bersama sehingga ketika akhir tahun pengurus BUMDes memberikan sedikit santunan kepada masyarakat yang kurang mampu dan anak yatim piatu. Dan pemberian santunan ini bersumber dari pembagian laba dari BUMDes Maju Bersama.

\section{SIMPULAN}

Pendirian BUMDes Maju Bersama di Desa Sei Jawi-jawi dimaksudkan untuk upaya bersama antara masyarakat dengan Pemerintah Desa untuk mengembangkan potensi desa serta memenuhi kebutuhan masyarakat desa. Dalam Proses Pembentukan BUMDes Maju Bersama di Desa Sei Jawi-jawi dilakukan dengan beberapa tahapan, tahapan tersebut dibagi menjadi 3 (tiga) Tahapan yaitu Pra Musyawarah Desa, Musyawarah Desa dan Pasca Musyawarah Desa. Hal ini dilakukan untuk memberikan sosialisasi ide dan gagasan kepada masyarakat mengenai Badan Usaha Milik Desa. Selain itu di dalam Musyawarah Desa dilakukan tinjauan dan kajian ringkas mengenai potensi yang ada di desa sehingga muncul jenis usaha yang akan didirikan dalam Badan Usaha Milik Desa. Kemudian tahapan akhir adalah menetapkan Perdes mengenai pembentukan Badan Usaha milik Desa Sei Jawi-jawi Kecamatan Sei Kepayang Barat.

Hasil atau keuntungan dari BUMDes Maju Bersama sebagian dialokasikan untuk Penyertaan Modal, PADes, honor pengurus BUMDes, dana pendidikan dan dana sosial kepada Masyarakat Desa Sei Jawi-jawi. Peran modal sosial dalam pengelolaan Badan Usaha Milik Desa Maju Bersama di Desa Sei Jawi-jawi Kecamatan Sei Kepayang Barat ini dianggap masih belum cukup baik. Hal ini dilihat dari masih sedikitnya jaringan kerja sama antara BUMDes Maju Bersama dengan pihak ketiga. BUMDes Maju Bersama hanya bekerjasama dengan dua pengusaha kecil di wilayah Desa Sei Jawi-jawi Kecamatan Sei Kepayang Barat sehingga pengembangan BUMDes sedikit lambat dan kurang berkembang. Kemudian adanya Agunan dan jaminan pinjaman bagi masyarakat yang ditetapkan oleh Pihak BUMDes dan ini menunjukkan tidak adanya peran kepercayaan antara masyarakat dan pihak BUMDes Maju Bersama. Bunga pinjaman yang ditentukan oleh BUMDes Maju Bersama terlalu tinggi dan besaran bunganya hampir sama dengan koperasi yang ada. Kemudian masih adanya masyarakat yang tidak membayar atau belum melunasi pinjaman mereka ke BUMDes Maju Bersama hal ini dibuktikan dari Laporan Tahunan yang direkap oleh pengurus BUMDes Maju Bersama Desa Sei Jawi-jawi.

\section{DAFTAR PUSTAKA}

Adidjoyo, M dan Tjokromidjojo, B, (1988). Teori Dan Strategi Pembangunan Nasional, Jakarta: CV. Haji Masagung,

Adisasmita, R. (2006). Pembangunan Pedesaan dan Perkotaan. Graha Ilmu, Yogyakarta.

Agusyanto, R. (2007). Jaringan Soial Dalam Organisasi. Jakarta: PT Raja Grafindo.

Arikunto, S, (1998). pengelolaan kelas dan siswa. CV. Rajawali, Jakarta.

Badarruddin, (2005). Modal Sosial dan Pemberdayaan Masyarakat Nelayan Dalam Arif Nasution, Sublihar, Badaruddin (ed). Isuisu kelautan : Dari Kemiskinan Hingga Bajak Laut. Pustaka Pelajar : Yogyakarta.

Bannock, G, Baxter, R.E. dan Davis. E. (2004). A Dictionary Of Economics. Penguin Books Ltd, Inggris.

Bratakusumah. (2004). Perencanaan Pembangunan Daerah. PT. Gramedia Pustaka Utama, Jakarta.

Bryan \& White. (1987). Manajemen Pembangunan Negara Berkembang. LP3ES, Jakarta.

Damsar. (1997). Sosiologi Ekonomi. Bielefeld: PT Raja Grafindo Persada

Daryanto, (1997). Kamus Indonesia Lengkap, Surabaya : Apollo.

Didjaja, M. (2003). Transparansi Pemerintah. Jakarta: Rineka Cipta

Eko. (2015). Pemberdayaan Masyarakat Desa. PustaAka Pelajar, Yogyakarta.

Field, J. (2011). Modal Sosial (Social Capital). Edisi Indonesia. Kreasi Wacana, Yogyakarta

Fukuyama, F. (2001). Sosial Capitalc; Civil Soceity and Development, Third World Quarterly, Vol 22.

Fukuyama, F. (2002). Guncangan Besar: Kodrat Manusia dan Tata Sosial. Gramedia, Jakarta.

Harahap, S.S,, (1996), Teori Akuntansi Laporan Keuangan, Bumi Aksara, Jakarta.

Hasbullah, (2006). Otonomi Pendidkan. PT. Raja Grafindo Persada. Jakarta.

Hasibuan, M.S.P. (2001). Manajemen Sumber Daya Manusia, Bumi Aksara. Jakarta.

Hasibuan, M.S.P. (2004). Manajemen Edisi Revisi, Bumi Aksara. Jakarta.

Ibrahim, M, dkk. (2002). "Pembelajaran Kooperatif". Surabaya: University Press

Jalal, F. dan Supriadi, D, (2001). Reformasi Pendidikan dalam konteks otonomi daerah, Adicita Karya Nusa. Yogyakarta. 
Jamaludin, Nasrullah, Abdon. 2015. Sosiologi Pedesaan. Pustaka Setia, Bandung.

Jhingan, M.L. (2000). Ekonomi Pembangunan dan Perencanaan. PT. Raja Grafindo Persada, Jakarta

Krisna, L.L. (2003). Indikator \& Alat Ukur Prinsip Akuntabilitas, Transparansi \& Partisipasi. Jakarta : Sekretariat Good Public Governance Badan Perencanaan Pembangunan Nasional

Kurniawan \& Borni. (2015). Desa Membangun Indonesia. FPPD, Jakarta.

Lawang, R.M, (2004). Kapitasl Sosial Dalam Perspektif Sosiologi. Jakarta : FISIP Press

Leibo, J. (1995). Sosiologi Pedesaan. Andi Offset, Yogyakarta.

Manulang, M. (1990). Dasar-dasar Manajemen, Jakarta: Galiando.

Maryuni. (2008). Pembangunan Bumdes dan Pemberdayaan Pemerintah Desa. Pustaka Setia, Bandung.

Mawardi, M.J. (2007). Peranan Sosial Capitaldalam Pemberdayaan Masyarakat.Jurnal Pengembangan Masyarakat Islam. Volume III Nomor 2 Tahun 2007. Jurusan Pengembangan Masyarakat Islam. Fakultas Dakwah IAIN Raden Intan. Bandar Lampung

Nurcholis, H. (2011). Pertumbuhan dan penyelenggaraan Pemerintahan Desa. PT. Erlangga, Jakarta.

Nurhadi. (2003). Pendekatan Kontekstual. Departemen Pendidikan Nasional. Jakarta

Pusat Kajian Dinamika Sistem Pembangunan. (2007). Buku Panduan Pendirian dan Pengelolaan Badan Usaha Milik Desa. Departemen Pendidikan Nasional. Fakultas Ekonomi. Universitas Brawijaya.

Putnam, R.D. (1993). The Prosperous Community : sosial Capital and Public life. The American Prospect.

Putnam, R.D. (1995). Bowling Alone: The Collapse and Revival of American Community. America's Declining Social Capital.

Rahadjo. (1999). Sosiologi Pedesaan dan Pertanian. Gajah Mada University Press, Yogyakarta.

Ritzer, George - Douglas J. Goodman. (2007). Teori Sosiologi Modern. Jakarta: Kencana Predanan Media Group.

Robbins SP, dan Judge. (2008). Prilaku Organisasi Buku 2, Jakarta : Salemba Empat

Salam, D.S. (2004). Manajemen Pemerintahan Indonesia. Jakarta : Penerbit Djambatan.

Saragi. T.P. (2004). Mewujudkan Otonomi Masyarakat Desa Alternatif Pemberdayaan Masyarakat. IRE Press, Jakarta.

Siagian, S.P. (2016). Sitem Informasi Manajemen. Bumi Aksara. Jakarta.

Siti Irene Astuti D. 2009. Desentralisasi dan Partisipasi dalam Pendidikan, UNY : Yogyakarta
Soekanto, S. (1990). Sosiologi Suatu Pengantar. PT. Raja Grafindo Persada : Jakarta.

Soemantri. (2011). Pedoman Penyelenggaraan Pemerintahan Desa. Fokusmedia, Bandung.

Stoner, F. dan Gilbert (1995). Pengantar Bisnis. Graha Ilmu. Yogyakarta.

Sudarsono. (2010). Koperasi Dalam Teori Dan Praktek. Rineka Cipta, Jakarta.

Sukirno, S. (2006). Mikroekonomi Teori Pengantar. Rajawali Pers, Jakarta.

Sule, E.T. \& Saefullah, K, (2009). Pengantar Manajemen. Kencana Perdana Media, Jakarta.

Sumpeno, W. (2011). Perencanan Desa Terpadu. Edisi Kedua. Reinforcement Action and Development. Banda Aceh.

Suryana. (2013). Ekonomi Kreatif. Salemba, Jakarta. Syahrudin, dkk. (2000). Manajemen Pemerintah Baru, Edisi Satu. Cetakan Pertama, Jakarta

Tanjung, A.H, (2010). Penata usahaan dan Akuntansi Keuangan Daerah Edisi 3. Jakarta. Salemba Empat.

Terry, G. R. (2003). Prinsip-prinsip Manajemen. PT. Bumi Aksara : Jakarta.

Tjokroamdjojo, B (1997). Manajemen Pembangunan. LP3ES, Jakarta.

Vipriyanti, N.U.. (2011). Modal Sosial \& Pembangunan Wilayah (mengkaji succes story pembangunan di Bali). Universitas Brawijaya Press : Malang.

Wahyudin, S. (2011). Buku Perencanaan Desa Terpadu. Pustaka Indonesia, Jakarta

Wibowo. (2007). Manajemen Kinerja. Jakarta : PT. Raja Grafindo Parsada.

Widjaya, H. (2003). Otonomi Desa. PT. Grafindo Persada, Jakarta.

Widjaya, H. (2014). Otonomi Daerah dan Daerah otonom. PT. RajaGrafindo Persada, Jakarta.

Yustika, A.E. et al, (2013), Proyeksi Ekonomi 2014: Akankah Krisis Berlanjut? INDEF, Jakarta

Zulkarnaen, M.R. (2016). Pengembangan Potensi Ekonomi Desa Melalui Badan Usaha Milik Desa (BUMDes) Pondok Salam Kabupaten Purwakarta. Jurnal Dharmakarya Unpad, Vol.5, No.1.

\section{Peraturan-Peraturan}

UU Nomor 32 Tahun 2004 Tentang Pemerintahan Daerah

UU Nomor 6 Tahun 2014 Tentang Desa

PP Nomor 72 tahun 2005 tentang Desa

PP Nomor 43 Tahun 2014 tentang Peraturan pelaksanaan undang-undang Nomor 6 Tahun 2014 tentang Desa

PP Nomor 47 tahun 2015 tentang Perubahan tentang Peraturan pelaksanaan undangundang Nomor 6 Tahun 2016 tentang Desa

Peraturan Menteri Desa, Pembangunan Daerah Tertinggal dan Transmigras No. 4 Tahun 
Zulpahmi, Badaruddin \& Humaizi, Peran Modal Sosial dalam Pengelolaan Badan Usaha Milik Desa Maju 